Revue bibliographique pour le domaine irano-aryen

\title{
Amélie Kuhrt. " Reassessing the Reign of Xerxes in the Light of New Evidence »
}

\section{Astrid Nunn}

\section{(2) OpenEdition}

1 Journals

\section{Édition électronique}

URL : http://journals.openedition.org/abstractairanica/42562

DOI : 10.4000/abstractairanica.42562

ISBN : 1961-960X

ISSN : 1961-960X

Éditeur :

CNRS (UMR 7528 Mondes iraniens et indiens), Éditions de l'IFRI

Référence électronique

Astrid Nunn, " Amélie Kuhrt. "Reassessing the Reign of Xerxes in the Light of New Evidence » », Abstracta Iranica [En ligne], Volume 37-38-39 | 2018, document 6, mis en ligne le 10 mars 2018, consulté le 28 septembre 2020. URL : http://journals.openedition.org/abstractairanica/42562 ; DOI : https://doi.org/10.4000/abstractairanica.42562

Ce document a été généré automatiquement le 28 septembre 2020

Tous droits réservés 


\title{
Amélie Kuhrt. « Reassessing the Reign of Xerxes in the Light of New Evidence »
}

\author{
Astrid Nunn
}

\section{RÉFÉRENCE}

Amélie Kuhrt. « Reassessing the Reign of Xerxes in the Light of New Evidence », in Michael Kozuh, Wouter F. M. Henkelman, Charles E. Jones, Christopher Woods (eds.). Extraction \& Control: Studies in Honor of Matthew W. Stolper. Studies in Ancient Oriental Civilization 68. Chicago, The Oriental Institute of the University of Chicago, 2014, p. 163-169.

1 Xerxes n'est pas le destructeur de la Babylonie, mais bien son réorganisateur et réformateur.

\section{AUTEURS}

\section{ASTRID NUNN}

Université de Munich 